
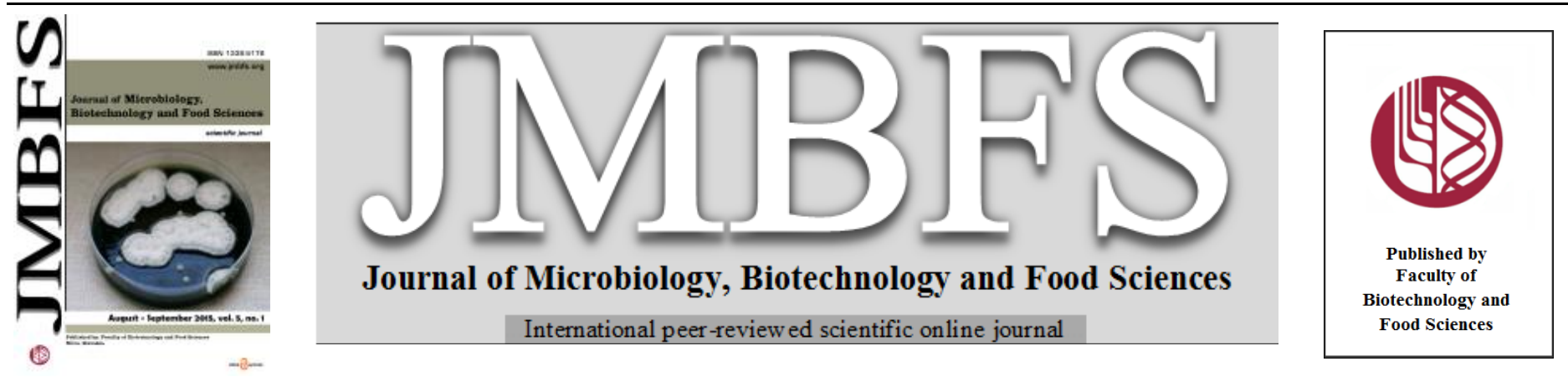

\title{
16S RRNA BASED PHYLOGENETIC ANALYSIS OF LACTOBACILLUS PLANTARUM ISOLATED FROM VARIOUS FERMENTED FOOD PRODUCTS OF ASSAM
}

\author{
Vinita Malik ${ }^{1}$ Utpala Devi ${ }^{1}$, R.N.S Yadav ${ }^{2}$ Jagadish Mahanta ${ }^{1}$.
}

Address(es):

${ }^{1}$ Regional Medical Research Centre, N E Region (ICMR), Post Box-105, Dibrugarh, Assam, 786001.

${ }^{2}$ Centre for studies in Biotechnology, Dibrugarh University, Assam, 786004.

*Corresponding author: jmahanta@gmail.com

doi: 10.15414/jmbfs.2015.5.1.20-22

\section{ARTICLE INFO}

Received 19.9. 2014

Revised 9. 5. 2015

Accepted 19. 5. 2015

Published 1. 8. 2015

Short communication

OPEN ${ }_{\text {ACCESS }}$

\section{ABSTRACT}

Although the isolation of Lactobacillus plantarum, a lactic acid bacteria from 'khorisa', a fermented food product of Assam, has been previously reported but the study on diversity among different species was left unexplored. Moreover, identification of those isolates was based on conventional and species specific polymerase chain reaction. However, in this study an attempt was made to identify and study the diversity of $L$. plantarum from fermented food products of Assam based on 16S rRNA gene sequence analysis. The phylogenetic tree revealed that most of the study isolates are closely related to L. plantarum strains from Tibet plateau (Silage) and Italy (Sicily).

Keywords: Lactobacillus plantarum, Assam ,16S rRNA gene, phylogenetic analysis

\section{INTRODUCTION}

Lactic acid bacteria (LAB) are beneficial organism and have been isolated from various fermented food products globally (Adnan and Tan, 2007; Tamang $e t$ al., 2012).The genus Lactobacillus contains more than 100 species and is the largest group of family Lactobacteriaceae (Canchaya et al., 2006). They are reported to be beneficial for human health (Paolillo et al., 2009; Kumar et al., 2011; Grover et al., 2012; O'Flaherty and Klaenhammer, 2012; Wang et al., 2012). Various fermented foods are consumed by people in Assam, a state with cultural and ethnic diversity. Isolation of Lactobacillus plantarum, a LAB from 'khorisa, a fermented food product of Assam has been previously reported (Malik et al., 2014). Identification of those isolates was based on conventional and species specific polymerase chain reaction (PCR). Based on these methods absolute differences between isolates belonging to same species cannot be determined. Phylogenetic analysis based on 16S rRNA gene sequences is a reliable method used globally to study such microbial biodiversity (Vandamme et al., 1996). This method makes it possible to identify bacteria to the genus or species level by comparison with databases in the public domain. It can help trace phylogenetic relationship from various sources. This study is an attempt to study the diversity of $L$. plantarum from different fermented food products of Assam based on $16 \mathrm{~S}$ rRNA gene sequence analysis.

\section{MATERIALS AND METHODS}

\section{Isolation of bacteria and maintenance}

A total number of 51 L. plantarum were isolated from 80 different fermented food products including khorisa (fermented bamboo shoot), fermented tomato, hukoti (fermented local fish) collected from rural areas of Dibrugarh district, Assam. For isolation, samples were inoculated in de Man, Rogosa and Sharpe (MRS) medium at $37^{\circ} \mathrm{C}$ and identified accordingly (Bergey and Breed, 2001) and stored at $4{ }^{\circ} \mathrm{C}$. For long term preservation, the isolates were kept in $30 \%(\mathrm{v} / \mathrm{v})$ glycerol at $-80^{\circ} \mathrm{C}$.

\section{Genomic DNA Isolation}

For the isolation of DNA, a pure colony was inoculated into $1.5 \mathrm{ml}$ MRS broth and incubated overnight at $37^{\circ} \mathrm{C}$. Bacterial cells were harvested by centrifugation for 10 minutes at $5000 \mathrm{~g}$, supernatant discarded and pellet was resuspended in Gram-positive bacteria lysis buffer (20 mM Tris-HCl, pH 8.0,2 mM EDTA, 1.2
$\%$ Triton X-100, and lysozyme $20 \mathrm{mg} / \mathrm{ml}$ ) and incubated at $37^{\circ} \mathrm{C}$ for 30 minutes DNA was recovered from the resulting sample using Gene JET Genomic DNA Purification kit (Fermentas, Thermo scientific, Waltham, Massachusetts, USA) according to the manufacturer's instruction. Briefly, to the above suspension Lysis solution and Proteinase $\mathrm{K}$ were added, incubated at $56^{\circ} \mathrm{C}$ for 30 minutes After complete lysis of cells, RNase A solution was added and incubated at room temperature for 10 minutes. Then $50 \%$ ethanol was added and whole lysate was transferred to purification column, centrifuged $(14,000 \mathrm{~g}$ for $2 \mathrm{~min})$ and washed twice with washing buffer.DNA was finally recovered by elution with buffer (10 $\mathrm{mM}$ Tris- $\mathrm{HCl}, 1 \mathrm{mM}$ EDTA) and frozen at $-20^{\circ} \mathrm{C}$ for later use.

\section{S r RNA gene amplification}

Genomic DNA of the isolates were used for amplification of 16S rRNA gene The universal 16S rRNA primers, forward primer 16S rRNA For (5'AGAGTTTGATCCTGGCTCAG-3') and reverse primer 16S rRNA Rev (5'ACGGCTACCTTGTTACGACTT-3') procured from Promega, (Madison, Wisconsin, USA) were used for PCR. The reaction was carried out in a volume of $50 \mu \mathrm{l}$. The PCR mixture contained $25 \mu \mathrm{l}$ of PCR Master Mix $2 \mathrm{X}(50 \mathrm{U} / \mathrm{ml}$ Taq polymerase, $400 \mu \mathrm{M}$ dNTP's, $3 \mathrm{mM} \mathrm{MgCl}$; Promega, USA), $5 \mu \mathrm{l}$ of each forward and reverse primer (10 $\mu \mathrm{M}$ each, IDT synthesized), $5 \mu \mathrm{l}$ of DNA and 15 $\mu 1$ of Nuclease free water (Promega, Madison, Wisconsin, USA) Amplification conditions were: 4 minutes of initial denaturation at $94^{\circ} \mathrm{C}, 1$ minute denaturation at $94^{\circ} \mathrm{C}, 1$ minute of primer annealing at $58^{\circ} \mathrm{C}, 2$ minutes elongation at $72^{\circ} \mathrm{C}$ for 35 cycles and a final extension of 7 minutes at $72^{\circ} \mathrm{C}$. The reactions were carried out in a thermal cycler (Veriti 9902, Applied Biosystem, Singapore).

\section{Electrophoresis}

A $10 \mu 1$ of PCR amplified product was electrophoresed on ethidium bromide stained $1.5 \%(\mathrm{w} / \mathrm{v})$ agarose gel in $1 \mathrm{X}$ TAE buffer at $100 \mathrm{~V}$ for 40 minutes, visualized and photographed under gel documentation system (GELLOGIC 2200 Image System, Kodak, USA) . A low range DNA ladder (100 bp) (Promega, Madison, Wisconsin, USA) was used as a molecular weight marker.

\section{Sequencing of the $16 \mathrm{~S}$ rRNA gene}

The 16S rRNA gene from the isolate was amplified. The amplification product was purified using the High Pure PCR Product purification kit (Roche, Mannheim, Germany).Briefly to $100 \mu 1$ of PCR product $500 \mu 1$ of binding buffer 
was added, mixture applied to high pure filter tube and centrifuged at maximum speed for 1 minute. Flow through was discarded and washed twice with washing buffer. Finally purified product was eluted in $1.5 \mathrm{ml}$ microcentrifuge tube for further usage. Sequencing was done by Sanger's method using an automated genetic analyser (Make: ABI, Model: 3100, California, USA).

\section{Sequence alignment of the 16S rRNA gene}

The 16S rRNA gene sequences of above mentioned isolates were compared with homologous sequences obtained from the BLAST analysis (http://blast.ncbi.nlm.nih.gov/Blast.cgi). Multiple sequence alignment was carried out by Clustal W (Thompson et al., 1994) and later phylogenetic analysis was performed using MEGA 6.0 (Tamura et al., 2013a).The isolates under study were assigned Gen bank accession number KJ160442, KJ160443, KJ160444 and KJ 160445 .

\section{RESULTS AND DISCUSSION}

The 16S rRNA gene sequence was analyzed for the four isolates from differen fermented food products. The PCR of $16 \mathrm{~S}$ rRNA gene gave an approximately 1500 bp amplicon (Fig. 1)

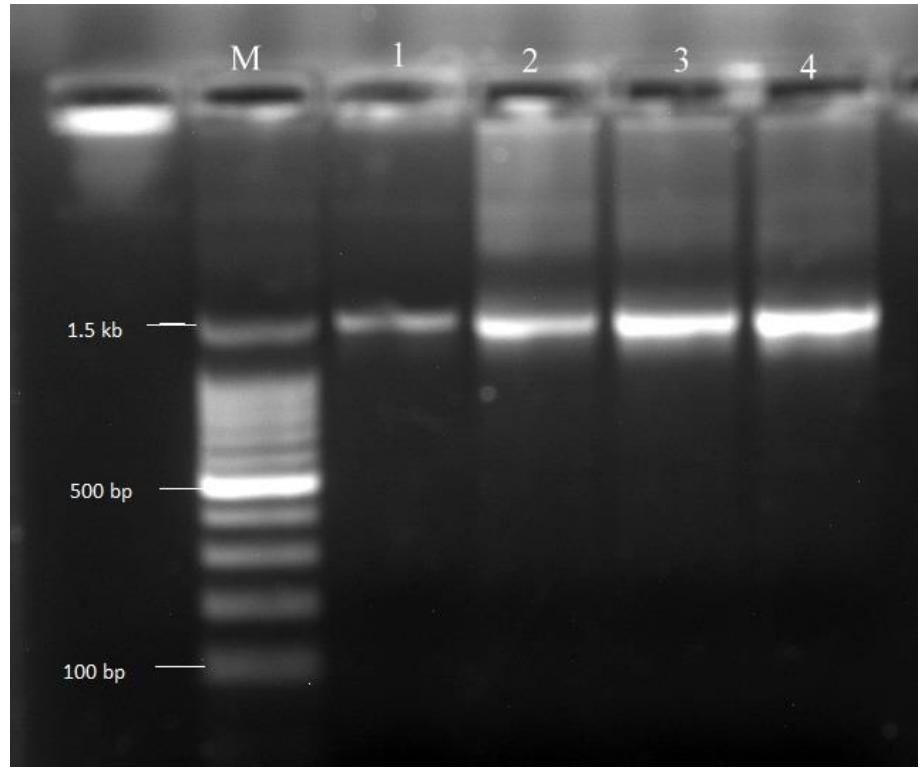

Figure 1 Agarose gel $(1.5 \%)$ showing PCR products of 16S rRNA gene of isolates; Lane M: 100 bp molecular weight marker, Lane 1-4: amplified product of study isolates

The evolutionary history was inferred using the UPGMA method (Sneath and Sokal, 1973). The optimal tree with the sum of branch length $=0.00835157$ is shown. The evolutionary distances were computed using the Maximum Composite Likelihood method (Tamura et al., 2004b) and are in the units of the number of base substitutions per site. The analysis involved 16 nucleotide sequences. Codon positions included were $1^{\text {st }}+2^{\text {nd }}+3^{\text {rd }}+$ Noncoding. All positions containing gaps and missing data were eliminated. There were a total of 320 positions in the final dataset. The evolutionary analysis also revealed that all the isolates were closely related to L. plantarum (Fig.2).

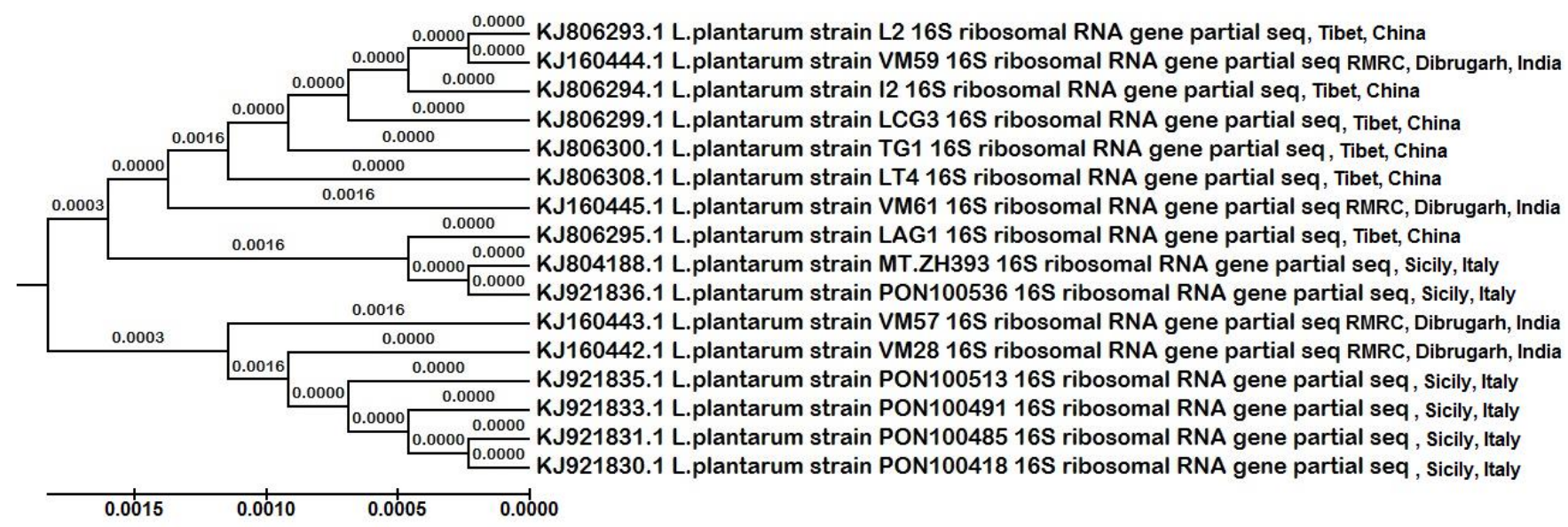

Figure 2 Phylogenetic tree based on 16S rRNA gene sequences of the four isolates compared with homologous closely related L. plantarum species using the MEGA v6.0 program by UPGMA method

L. plantarum is a heterogeneous and versatile species that is widely distributed in the environment with high levels of carbohydrates such as food products (dairy products, fermented meat) as well as fermenting plant-derived substrates (Siezen and van Hylckama Vlieg,2011). Studies have reported high inter strain diversity (Pisano M.B. et al., 2010). Different studies from India have demonstrated diversity of LAB strains from dairy as well non diary food products (Patel A. et al., 2012; Balamurugan R. et al., 2014). The present study suggests the presence of genotypic variation within the $L$. plantarum isolated from different fermentrd food products of this region. Isolates L. plantarum VM 59 and VM 61 isolated from 'khorisa' (Gen bank accession number KJ16044, KJ160445) were found to be similar to strains isolated from Silage in Tibetan plateau. Tibet being a part of neighbouring country could explain the similarity. Previously isolated $L$. planatrum from Tibetan region had shown probiotic properties like cholesterol assimilation, co-precipitation and cholesterol lowering effect (Huang et al., 2013 and Zheng et al., 2013). Thus, similarly screening for probiotic potential on our isolates can be explored. Isolates L. plantarum VM 28 from 'hukoti' and VM 57 from 'fermented tomato' were found be similar to strains isolated from Sicily, Italy. Increase in communication across vast geographical areas during recent years may be one of the reasons for such similarity. Multiple sequence alignment of isolates showed that nucleotide position 437-757 were conserved among all the four isolates with difference of single base pair in one isolate (KJ160443) (Fig. not shown). Comparison of our isolates with those from North East India could not be attempted due to unavailability of previous reports from this region.

\section{CONCLUSION}

We conclude that the identification of the study isolates was confirmed by $16 \mathrm{~S}$ rRNA gene sequencing. The phylogenetic analysis revealed the similarity of our isolates with those of Tibet and Sicily. 


\section{REFERENCES}

BALAMURUGAN, R., CHANDRAGUNASEKARAN, A. S., CHELLAPPAN, G., RAJARAM, K., RAMAMOORTHI, G., RAMAKRISHNA, B.S.2014 Probiotic potential of lactic acid bacteria present in homemade curd in southern India. Indian J Med Res, 140(9), 345-355.

BERGEY, D. H., BREED, R. S.2001. Bergey's manual of systematic bacteriology, edited by Garrity GM, 2nd ed, Springer, New York. http://dx.doi.org/10.1007/978-0-387-21609-6

CANCHAYA, C., CLAESSON, M.J., FITZGERALD, G.F., SINDEREN, D.V. O'TOOLE, P.W. 2006. Diversity of the genus Lactobacillus revealed by comparative genomics of five species. Microbiology, 152, 3185-3196. http://dx.doi.org/10.1099/mic.0.29140-0

GROVER, S., KUMAR. A., SRIVASTAVA ,A.K., BATISH, V.K. 2012.Probiotics as functional food ingredients for augmenting human health. Innovation in Healthy and Functional Foods. CRC Press, Taylor \& Francis Group, Boca Raton, 387-417. http://dx.doi.org/10.1201/b13022-29

HUANG, Y.1., WU, F., WANG ,X., SUI, Y., YANG ,L., WANG, J. 2013. Characterization of Lactobacillus plantarum Lp27 isolated from Tibetan kefir grains: a potential probiotic bacterium with cholesterol-lowering effect, $J$ Dairy Sci, 96(5), 2816-25. http://dx.doi.org/10.3168/jds.2012-6371

KUMAR, R., GROVER, S., BATISH, V.K.2011.Hypocholesterolaemic effect of dietary inclusion of two putative probiotic bile salt hydrolase producing Lactobacillus plantarum strains in Sprague-Dawley rats. Br J Nutr, 105, 561573. http://dx.doi.org/10.1017/s0007114510003740

MALIK, V., DEVI, U., YADAV, R.N.S., MAHANTA. J. 2014. Isolation, identification and antibacterial properties of L.plantarum from 'Khorisa', a traditional food product of Assam. International Journal of Pharmaceutical Research and Health Care, 4(4) ISSN No: 2249-5738.

MOHD, ADNAN, A.F. TAN, I.K. 2007. Isolation of lactic acid bacteria from Malaysian foods and assessment of the isolates for industrial potential. Bioresour Technol 98, 1380-1385. http://dx.doi.org/10.1016/j.biortech.2006.05.034

O'FLAHERTY, S., KLAENHAMMER, T.R. 2010. The role and potential of probiotic bacteria in the gut, and the communication between gut microflora and $\begin{array}{lllll}\text { gut/host. } & \text { Int. } & \text { Dairy } & J & 20,262\end{array}$ 268.http://dx.doi.org/10.1016/j.idairyj.2009.11.011

PAOLILLO, R., CARRATELLI, C.R., SORRENTINO, S., MAZZOLA, N., RIZZO, A.2009 .Immunomodulatory effects of Lactobacillus plantarum on human colon cancer cells. Int Immunopharmacol ,9,12651271.http://dx.doi.org/10.1016/j.intimp.2009.07.008

PATEL, A., LINDSTRÖM,C., PATEL,A., PRAJAPATI, J.B., HOLST, O.2012.Probiotic properties of exopolysaccharide producing lactic acid bacteria isolated from vegetables and traditional Indian fermented foods. International $\begin{array}{llll}\text { Journal of Fermented Foods, } & 1(1), 87-101\end{array}$ http://dx.doi.org/10.1016/j.fbio.2013.10.002

PISANO,M.B., PATRIGNANI, F., COSENTINO,S., GUERZONI,M.E., FRANZ, C.M.A.P., HOLZAPFEL .W.H.2010. Diversity and functional properties of Lactobacillus plantarum group strains isolated from Italian cheese products, Dairy Sci Technol, 91(1), 6576.doi:10.1051/dst/2010037

SIEZEN, R.J., VAN HYLCKAMA VLIEG, J.ET.2011.Genomic diversity and versatility of Lactobacillus plantarum, a natural metabolic engineer, Microbial Cell Factories , 10(Suppl 1),S3. http://dx.doi.org/10.1186/1475-2859-10-s1-s3

SNEATH, P.H.A., SOKAL, R.R. 1973.Numerical Taxonomy. Freeman, San Francisco

TAMANG, J.P., TAMANG, N., THAPA, S., DEWAN, S., TAMANG, B., YONZAN, H., RAI, A.K., CHATTRI, R., CHAKARABARTY, J., KHAREL, N 2012.Microorganism and ethnic value of ethnic fermented foods and alcoholic beverages from North East, India. Indian J Tradit Knowledge, 11,7-25.

TAMURA, K., STECHER, G., PETERSON, D., FILIPSKI, A., KUMAR, S .2013a. MEGA6: Molecular Evolutionary Genetics Analysis

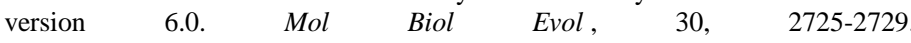
http://dx.doi.org/10.1093/molbev/mst197

TAMURA, K., NEI, M., KUMAR, S. 2004b. Prospects for inferring very large phylogenies by using the neighbor-joining method. Proc Natl Acad Sci U S A, 101 (30),11030-11035 . http://dx.doi.org/10.1073/pnas.0404206101

THOMPSON, J. D., HIGGINS, D. G., GIBSON, T, J. 1994. CLUSTAL W: improving the sensitivity of progressive multiple sequence alignment through sequence weighting, position-specific gap penalties and weight matrix choice Nucleic Acids Res. 22, 4673-4680. http://dx.doi.org/10.1093/nar/22.22.4673 VANDAMME, P., POT, B., GILLIS, M., DE, VOS. P., KERSTERS, K. SWINGS, J.1996. Polyphasic taxonomy, a consensus approach to bacterial systematics. Microbiol. Rev. 60,407-438.

WANG, J., ZHANG, H., CHEN, X., CHEN, Y., BAO, M.Q. 2012. Selection of potential probiotic lactobacilli for cholesterol-lowering properties and their effect on cholesterol metabolism in rats fed a high-lipid diet. J Dairy Sci, 95, 16451654. http://dx.doi.org/10..3168/jds.2011-4768

ZHENG, Y., LU, Y., WANG, J., YANG, L., PAN, C., HUANG, Y.2013. Probiotic Properties of Lactobacillus strains isolated from Tibetan Kefir grains. PLOS ONE, 8(7).http://dx.doi.org/10.1371/journal.pone.0069868 